\title{
2018 年本溪市气候分析
}

\author{
李冰 孙秀恒 韩瑞 王焕毅 魏海宁 \\ 本溪市气象局 \\ DOI:10.32629/eep.v2i8.388
}

[摘要] 利用本溪市 2018 年气象资料,综合分析了本年度天气气候特征: 气温正常、降水偏多、光照偏多。结果表明本年度年平均气温7.4摄氏 度；年总降水量935.0毫米,较历年值多112.0毫米。年日照总时数2394.0小时。

[关键词] 2018年; 本溪市; 气候分析

\section{引言}

目前, 全球气候趋于变暖, 气候变化对工农业及人们的日常生活产生 重要影响, 逐渐成为全球关注的热点 ${ }^{[1-2]}$ 。关注气候变化, 加快对气候变化 趋势的分析研究, 对经济社会的可持续发展和国家安全具有十分重要的战 略意义。在全球气候变暖背景的气候变化下, 本溪地区是否也同样存在该 问题 ${ }^{[3]}$ 。

\section{1 基本情况}

本溪市气象局是国家基本气象站。简称基本站。本溪国家基本气象站 位于辽宁省本溪市明山区胜光街, 纬度 $41^{\circ} 18^{\prime} \mathrm{N}$, 经度 $123^{\circ} 47^{\prime} \mathrm{E}$, 观测 场海拔高度185.4米, 气压感应部分海报高度 186.4 米, 风度反应器距离地 面更高度 10.5 米。主要气候特点: 四季分明、雨热同季、温度变幅大、雨 量较充沛、日照充足、无霜期较短、山地和局地小气候明显。春季受季风 影响, 风大雨少, 空气干燥, 夏天炎热, 雨热同步, 秋季日照充足, 冬天寒冷 漫长。

\section{2 数据来源}

结果, 从而影响了环境监测水质采样管理工作。

\section{3 环境监测水质采样质量的优化管理措施}

3. 1 加强前期的管理工作

若想要保证检测结果的准确性, 就必须要加强前期的管理工作, 从而 保证后续工作的顺利进行, 对此, 要做好以下几点要求。第一, 加强对相关 文件的学习。检测人员若想要做好检测工作, 保证检测结果的准确性, 就必 须要十分熟悉相关文件和方案, 熟练掌握检测过程中各个环节的具体操作 和相关要求, 并且要在这基础上不断完善自身对于检测知识和技术的掌 握。第二, 准备好相关的检测设备。采样人员和检测人员等相关人员必须 要认真仔细的核对设备的型号和状态, 在使用之前, 要对设备进行认真严 谨的校对和检查, 保证设备能够正常使用, 同时, 也要对采取水样所需的容 器进行仔细检查, 保证所有的设备和容积都能够符合相关的要求, 满足检 测工作的需要。只有确定所需要的设备和器具等, 不存在任何的问题, 才能 够进行其他工作。

\section{2 加强现场采样的规范要求}

只有加强对现场采样的规范要求, 才能够更好的保证检测结果的准确 性, 同时, 也直接影响了对水质样品的质量管理。为了加强对现场采样的规 范要求, 必须要选用综合水平高专业能力强的检测人员和管理人员, 并对 相关人员进行提前培训, 保证相关人员都十分熟悉现场的规范要求, 并且 能够严格按照规范要求进行操作, 同时也能够及时解决突发情况和意外问 题, 将损失和影响降到最小。在实际采样过程中, 很容易忽略污染源工况这 一问题, 从而导致所采取的样品无法正常使用, 所以, 才让人员必须要熟练 掌握污染源的工况和废水治理工艺, 并且根据实际情况制定一个合理的采
资料来源于本溪市气象局, 本溪县气象局, 桓仁县气象局, 辽宁草河 口气象站利用 2018 年整编资料, 通过计算2018年年平均气温、降水和日 照等数据资料以及与常年比对得到数据, 对 2018 年度本溪市气候特征做 具体分析。

\section{3 气候分析}

3.1 全年整体气候分析

3. 1.1 气温

2018 年本溪地区年 $\left(1 \sim 12\right.$ 月) 平均气温 $7.4^{\circ} \mathrm{C}$, 和历年相同, 比去年同 期低 $0.6^{\circ} \mathrm{C}$ 。年极端最高气温为 $40.4^{\circ} \mathrm{C}$ (8月 2 和 3 日出现在明山区高台子街 道办事处塔峪村); 年极端最低气温 $-37.6^{\circ} \mathrm{C}$ (1月 26 日出现在桓仁县黑沟乡 大川村)。

\subsection{2降水量}

2018年本溪地区降水量为 935.0 毫米, 比历年多 112.0 毫米, 比去年同 期多276. 1 毫米。

3. 1.3 日照时数

样方案, 保证所采取水样的质量。

3. 3加强对设备的维护管理

为了保证水质采样工作的顺利进行, 必须要提高对设备维护管理的重 视度, 加强对设备的日常维护和后续保养管理, 再进行检测过程中也要严 格按照规范进行操作, 避免对设备产生较大的影响。在检测工作完成之后, 要对设备进行后续保养, 在对设备的清理检查过程中, 如果发现任何问题 应当及时上报并采取有效的方法解决, 之后要将故障问题以及造成问题的 原因, 做好记录工作, 保障设备的正常使用。

\section{4 结束语}

环境监测中十分重要的一部分就是水质监测, 只有加强水质检测, 才 能够为人们提供更安全的水源。影响环境监测水质采样管理工作的因素有 许多方面, 相关人员要充分考虑到影响材料管理工作的各个方面, 并且采 取科学有效的手段进行解决, 加强对环境监测水质采样质量工作的前期管 理, 同时也要加强对现场采样的规范要求, 在开展检测工作之前, 也要对设 备进行维护和检查, 保证设备的正常使用, 进一步加强对环境的监测和水 质采样质量的优化管理。

\section{[参考文献]}

[1]王艳荣. 环境监测水质采样质量管理 [J]. 资源节约与环 保,2019,(04):60+66.

[2] 莫亚贤.环境监测水质采样质量管理的研究 [ J]. 环境与发 展,2018,30(09):147+149.

[3] 曲冬梅.分析环境监测水质采样质量管理 [J].资源节约与环 保,2017,(04):99. 
2018年本溪地区日照时数为 2394.0 小时, 比历年多101. 8 小时, 比去年 同期少 245.7 小时。

3.2 2018年各季气候概况

3. 2. 1冬季气候概况 (2017年12月～2018年2月)

冬季本溪气候特点是: 气温偏低、降水偏少、光照偏多。

平均气温为 $-10.4^{\circ} \mathrm{C}$, 比历年低 $1.2^{\circ} \mathrm{C}$, 比去年同期低 $2.8^{\circ} \mathrm{C}$; 极端最高 气温为 $8.2^{\circ} \mathrm{C}$ (2018年2月 28 日出现在桓仁县五里甸子镇五里甸村), 极端最 低气温为 $-37.6^{\circ} \mathrm{C}$ (2018年1月 26 日出现在桓仁县黑沟乡大川村)。降水量为 17. 4 毫米, 比历年少 12.4 毫米, 比去年同期少 26.9 毫米。日照时数为 580.2 小时, 比历年多 58.1 小时, 比去年同期多 52.3 小时。

3.2 .2 春季气候概况 (2018年3 5月)

2018年春季气候特点: 气温偏高、降水偏少、光照略少。

平均气温为 $9.4^{\circ} \mathrm{C}$, 比历年高 $1.0^{\circ} \mathrm{C}$, 比去年同期低 $0.1^{\circ} \mathrm{C}$; 极端最高气 温为 $32.6^{\circ} \mathrm{C}$ (4月 24 日出现在本溪县草河口镇), 极端最低气温为 $-27.5^{\circ} \mathrm{C}(3$ 月 2 日出现在桓仁县黑沟乡大川村)。降水量为 115.3 毫米, 比历年少 18.6 毫米, 比去年同期多 19.4 毫米。日照时数为 654.2 小时, 比历年少 10.4 小时, 比去年同期少 135.8 小时。

3. 2. 3夏季气候概况 (2018年6 8月)

2018年夏季气候特点是: 气温略高、降水偏多、光照略多。

平均气温为 $22.3^{\circ} \mathrm{C}$, 比历年高 $0.3^{\circ} \mathrm{C}$, 比去年同期低 $0.3^{\circ} \mathrm{C}$; 极端最高气 温为 $40.4^{\circ} \mathrm{C}$ (8月 2 和 3 日出现在明山区高台子街道办事处塔峪村), 极端最 低气温为 $6.4^{\circ} \mathrm{C}$ (6月 3 日出现在桓仁县八里甸镇岱龙江村)。降水量为 628.2 毫米, 比历年多107. 1 毫米, 比去年同期多 238.9 毫米。日照时数为 557.6 小 时, 比历年多8.2小时, 比去年同期少 109 小时。

3.2 .4 秋季气候概况 (2018年9 11月)

2018年秋季气候特点是: 气温正常、降水偏多, 光照偏多。

平均气温为 $8.2^{\circ} \mathrm{C}$, 和历年相同, 比去年同期高 $0.1^{\circ} \mathrm{C}$; 极端最高气温为 $30.9^{\circ} \mathrm{C}$ (9月 1 日出现在高台子街道办事处高台子中学), 极端最低气温为 $-19.3^{\circ} \mathrm{C}$ (11月 23 日出现在八里甸镇岱龙江村)。降水量为 164.5 毫米, 比历 年多 26.3 毫米, 比去年同期多 26.6 毫米。日照时数为 597.8 小时, 比历年多 41.5 小时, 比去年同期少 28.2 小时。

\section{4 主要气象灾害天气过程}

今年主汛期本溪地区经历了 “ $7.26 \sim 8.4$ ”高温灾害, “ $8.7 \sim 8$ ” “8. 13 15”、“8.19 21”、“8.23 24” 暴雨天气过程。

4.1 “7. 26 8. 4” 高温灾害

受今年赤道地区台风活跃, 导致副热带高压位置异常偏北, 且长时间 盘踞。7月 28 日以来, 我市连续 8 天出现 $35^{\circ} \mathrm{C}$ 以上高温天气, 平均气温为 30.1 ${ }^{\circ} \mathrm{C}$, 较历年同期偏高 $5.9^{\circ} \mathrm{C}$ (历年同期平均气温为 $24.2^{\circ} \mathrm{C}$ )。此次高温灾害是
本溪地区1953年有气象记录记载以来最严重的灾害; 高温灾害持续时间之 长、影响范围之广、危害之重是历史所没有的。据市农委统计, 由于高温 造成的干旱灾害, 农业受灾面积 33.97 万亩, 其中成灾面积 18.9 万亩, 绝收 2. 42 万亩。

\section{2 “8.7 8” 暴雨天气过程}

受副热带高压和西风槽共同影响, 8月7日1时至8日7时, 我市出现强 降雨天气; 全市 4 个国家气象观测站和 56 个区域自动站, 60 个自动站中有 59 个出现暴雨以上天气过程。最大降雨量为明山区高台子街道办事处塔 峪村 190.9 毫米; 1小时最大降水量出现在明山区高台子街道办事处塔峪 村68. 3 毫米, 12 小时最大降水量出现在明山区高台子街道办事处塔峪村 189. 3 毫米。

\section{3 “8. 13 15” 暴雨天气过程}

受副热带高压边缘暖湿气流和西风带冷空气共同影响, 8月 13 日 08 时 至 15 日 07 时, 我市出现强降雨天气, 雨量分布不均。全市 61 个自动气象观测 站中有 51 个出现暴雨以上天气过程。最大降水量为南芬区郭家街道办事处 赵家村 240.3 毫米; 1 小时最大降水量出现在南芬区郭家街道办事处赵家村 54.4 毫米, 12 小时最大降水量出现在南芬区郭家街道办事处赵家村 195.0 毫米。

4.4 “8. 19 21” 暴雨天气过程

受第18号台风 “温比亚” 外围云系和冷空气共同影响, 8月19日08时至 21 日07时, 我市出现大雨到暴雨、局部大暴雨天气, 雨量分布不均。全市61 个自动气象观测站中有 31 个出现暴雨以上天气过程。最大降水量为桓仁县 北甸子乡 156.2 毫米; 1 小时最大降水量出现在桓仁县北甸子乡 26.2 毫 米, 12 小时最大降水量出现在桓仁县北甸子乡 137.7 毫米。

4.5 “8.23 24” 暴雨天气过程

受第19号台风 “苏力” 外围云系影响, 8月23日14时至24日14时, 桓仁 县出现暴雨、局部大暴雨天气。全市 61 个自动气象观测站中有 10 个出现暴 雨以上天气过程。最大降水量为桓仁县五里甸子镇 127.3 毫米; 1 小时最大 降水量出现在桓仁县沙尖子村 17.9 毫米, 12 小时最大降水量出现在桓仁县 五里甸子镇 94.2 毫米。

[参考文献]

[1]任中怡,王娜, 张志国,等.1981-2010年盘山县气候特征变化趋势 分析[J].现代农业科技,2015,(9):259-261.

[2]陈鹏狮,马维娟.2017年辽宁省农业气候展望及风险预估[J].新农 业,2017,(6):25-26.

[3]孙秀恒,李冰,韩瑞, 等.2017 年本溪市气候分析 [J].安徽农学通 报,2018,24(19):120+123. 